\title{
The EU's REDD+ Policy Developments and the Lessons from the Policy Implementation in West Papua and Papua, Indonesia
}

\author{
Hyuk Jeong ${ }^{1}$ \\ ${ }^{1}$ Institute for EU Studies, Hankuk University of Foreign Studies, Seoul, Republic of Korea \\ Correspondence: Hyuk Jeong, Haneul@501-1101, Haneul 1 Ro 25, Ilsandong Ku, Koyang City, Kyongki \\ Province, Republic of Korea. Tel: 82-010-4360-2377.
}

Received: January 16, 2018

Accepted: May 7, 2018

Online Published: May 16, 2018

doi:10.20849/ajsss.v3i2.385

URL: https://doi.org/10.20849/ajsss.v3i2.385

\begin{abstract}
Despite its short history of development, the Reducing Emissions from Deforestation and Forest Degradation (REDD+) policy has started to establish itself as an effective policy for securing carbon offsets for large emitters of greenhouse gases including the European Union (EU). Corresponding to the direction of the international climate change policy area, this article primarily presents the current state of the EU REDD+ policy implementation. It offers considerations and suggestions to overcome the challenges facing an ongoing EU REDD+ project in West Papua and Papua in Indonesia to better direct the policy. First, to provide a primary overview of EU REDD+ policy developments, the article analyses the policy developments at the EU level, including its legal basis, as well as the roles of the EU's REDD+ policy as it relates to institutions. Second, this article presents the background of the ongoing project in West Papua and Papua, Indonesia, and identifies and analyses the main challenges facing the implementation of the ongoing project. Third, the article discusses the author's own view regarding these challenges. Finally, in the conclusion, it discusses the prospects and limitations of the EU's REDD+ policy.
\end{abstract}

Keywords: $\mathrm{CO}_{2}$, climate change, emissions, EU, policy, REDD+

\section{Introduction}

Forests provide humans with a place to live. Forests with high biodiversity are indispensable components for the fauna and flora as well, as they provide crucial habitat. Forests do not merely provide food, but also fresh (oxygenated) air to breathe. However, forests release $\mathrm{CO}_{2}$, one of the main greenhouse gases, into the atmosphere when they are subjected to anthropogenic disturbances. In this regard, deforestation and forest degradation are processes during which the emission of $\mathrm{CO}_{2}$ actively occurs. Thus, changes in land use and the destruction of forests contribute to increasing $\mathrm{CO}_{2}$ emissions. The European Commission recently announced that the emissions from deforestation and forest degradation account for up to $12 \%$ of the total amount of global $\mathrm{CO}_{2}$ emissions (European Commission, 2015a). Additionally, it has implemented the Reducing Emissions from Deforestation and Forest Degradation (REDD+) policy to mitigate $\mathrm{CO}_{2}$ emissions.

The aim of this article is to present and discuss the EU's REDD+ policy developments and the challenges facing the ongoing project as well as to suggest future policy direction. First, the article provides an overview and analysis of the EU REDD+ policy. Then, it identifies and discusses the main challenges facing a REDD+ project currently underway, and the author put forth possible solutions to these challenges in the latter part. Finally, the article presents the conclusion and the limitations of the article. The EU's REDD+ project in West Papua and Papua, Indonesia, was selected to discuss the EU's REDD+ policy implementation for a couple of reasons. First, the stage of the EU's REDD+ policy implementation in Indonesia is the most developed among Asian countries, including Indonesia, Laos, and Vietnam (European Forest Institute [EFI], 2014). Second, the EU REDD+ project underway in West Papua and Papua has officially announced the challenges it faces. While these challenges have been discussed broadly in the literature, further discussions are warranted to improve the future direction of the EU's REDD+ policy development in the article.

\section{Methodology}

Content on official websites for the European Commission and the United Nations Framework Convention on Climate Change Conference of Parties (UNFCCC COP), as well as legal documents from these sites, and 
especially those regarding the EU's REDD + policy, have been analyzed closely to support an informative discussion of the EU's policy developments. The contents have been organized, analyzed, and described chronologically. Regarding the legal basis of REDD+, the relevant literatures have been examined and analyzed. In analyzing the roles of institutions that are relevant to the EU's REDD+ policy, a thorough examination has been conducted, and the author has mainly compared the scope and functions of these institutions. The discussions regarding the Indonesian project have been analyzed and elaborated based on the documents that the official project website provides. Additionally, information regarding the policy challenges has also been obtained from these websites. The article aims to provide an in-depth discussion of the main challenges facing REDD+ by further analyzing and reviewing the relevant literatures.

\section{The EU's REDD+ Policy Developments}

\subsection{From RED to REDD+ at the Level of the $E U$}

After RED (Reducing Emissions from Deforestation) was proposed in the $11^{\text {th }}$ COP to the UNFCCC in 2005, the European Commission adopted a decision that paved the way for the development of the policy. As it was an approach that aimed to improve forest management and forest conservation in developing EU countries and it only stressed the use of aid programs, its scope differed substantially from the current EU REDD+ policy. There was no remarkable progress in the development of the REDD+ until 2007, when the Bali Road Map was rolled out in the Bali COP to the UNFCCC (UNFCCC, 2007). A set of concrete measures for the implementation of the Kyoto Protocol, including those regarding REDD, were agreed upon. Adopting the commitments under the Protocol, the EU began to formulate a number of policies that aimed to reduce greenhouse gas emissions. Because it was agreed that the afforestation and reforestation policy areas should be incorporated into CDM at the Bali COP, the EU pledged to cut tropical deforestation by $50 \%$ by 2030 (European Commission, 2008). However, the European Commission decided not to include the REDD in the European Union Emissions Trading System (EU ETS), as it maintained that the inventory of emissions, offsets, and removals of the $\mathrm{CO}_{2}$ emitted from forests and the agricultural sector was in the urgent need of a transparent and accurate reporting system for Measurement, Reporting, and Verification (MRV). Given the need for such a system for both REDD+ and afforestation and reforestation inventories, the EU decided not to include REDD+ in the CDM either because each Member State has different reasons for deforestation and forest degradation. This might make it difficult for EU Member States to reach an agreement regarding the effectiveness of REDD. A subsequent proposal from the European Commission outlined the funding mechanism of REDD+ (European Commission, 2008). It was primarily about reinforcing the existing REDD+ policies, and it stressed the importance of the commitments that the EU made under the Kyoto Protocol. It was more concerned with emphasizing how important it would be for the EU to come up with responses to global warming, rather than how to deal with REDD+-related issues and what measures should be used to tackle them. However, it has a significant meaning in that it proposed the importance of a funding mechanism for REDD+, and it signaled the possibility of REDD+ being included in carbon markets that issue carbon credits for industrial sectors. The European Council was supportive of the idea and left the door open for the chance of incorporating REDD+ carbon credits into the EU ETS (European Council, 2008). Another policy that increased the need for financial help for the implementation of the REDD+ was rolled out in 2008. It was the '2020 Climate and Energy Package' (European Commission, 2015a). This package served as a stepping stone for the EU's broader goal of providing a road map to a low-carbon economy by 2050 . The European Parliament approved a package that allocated 50\% of the proceeds from auctioning carbon credits to EU-level climate change mitigation and adaptation measures and policies. Additionally, following the Durban Conference in 2012, the European Council adopted a conclusion that urged rapid financing for REDD+ at the EU level, and it decided to comply with follow-up measures upon the establishment of the Green Climate Fund (European Council, 2012). Recently, the European Council adopted another conclusion that reaffirmed the need for a policy that was designed to integrate land use and forestry into the 2030 Framework for Climate and Energy Policies as soon as the needed technical conditions would allow (European Council, 2014). This indirectly reflects the Commission's previously mentioned perspective that the EU currently lacks the technological capacity to incorporate REDD+ into the EU ETS.

\subsection{Legal Basis of the EU REDD+}

Regarding the legal basis of the EU REDD+ policy, it was the revised EU ETS Directive that first alluded to the importance of reducing emissions from deforestation and forest degradation (European Commission, 2009). However, because the participating parties at the Durban Conference on Climate Change in 2011 agreed to revise the accounting rules with reference to $\mathrm{CO}_{2}$ sequestrations and emissions by the forestry and agricultural sectors (UNFCCC, 2011), the European Parliament and the Council have been committed to taking a corresponding action that required $\mathrm{EU}$ Member States to plan for actions regarding $\mathrm{CO}_{2}$ emissions that were related to forestry 
and agriculture (European Commission, 2015b). Because the accounting-related legislation has not been established, the EU has not set reduction targets for these sectors. However, it considers the inventory system to be firmly overarching, especially in the land use and land use change areas. Additionally, the European Commission considered the uncertainty and inaccuracy of the MRV as it prioritized the issues that needed to be addressed. Therefore, it will take a long time before a more transparent, accurate, and predictable system is established for REDD+. In summation, the concrete legal basis of the EU REDD+ is currently weak, and it will remain so until the inventory system is proven to be effective, at which point it will be incorporated into the carbon accounting rules. The following descriptions regarding the roles of EU REDD+-relevant institutions will be instrumental to helping one understand the picture of the current state of the EU's REDD+ policy implementation.

\subsection{The Roles of EU REDD+ Policy-Related Institutions}

\subsubsection{The Forest Law Enforcement Governance Trade (FLEGT) Action Plan}

The FLEGT comprises a number of measures that were designed to address the issues of illegal logging and its associated trade-related problems (European Commission, 2003). The plan was designed to eradicate the problems attributed to illegally produced timber and the demand for such timber inside the EU, and it is centered upon governance reforms. It is intended to strengthen multilateral cooperation and complement demand-based measures. In terms of multilateral cooperation, the EU is obligated to help its partner countries establish a legally sound supply chain to verify that imported timber is legally produced. A country needs to have a voluntary agreement to partner with the EU. The agreement, the Voluntary Partnership Agreement (VPA), provides both sides with a framework that enforces governance and laws that deal with problems stemming from deforestation and forest degradation. It conducts its measures in terms of consumption and production. It encourages both private sectors and EU countries to ensure that the timber products being purchased inside the EU are legal by implementing the EU Timber Regulation. Additionally, this plan also provides measures to avoid promoting investments for illegal logging. Regarding timber production, the countries that signed the VPA with the EU are supposed to be provided with technical and financial assistance from the EU to strengthen their forest governance and build up the production capacity. Furthermore, under the VPA, the EU is to aid countries in their fight against illegal logging to prevent illegal timber from entering the EU timber market (EFI, 2014)

\subsubsection{EU REDD+ Facility}

The EU REDD+ Facility was established in 2010 with the aim to aid the countries that have partnered with the EU under the VPA, particularly to improve their forest governance. The Facility also helps the EU address fundamentally problematic elements that trigger deforestation and forest degradation in these countries. It plays a pivotal role in promoting forest management in a sustainable manner in developing countries. It compensates developing countries for their efforts to reduce emissions from deforestation and forest degradation. Thus, the EU REDD+ Facility ensures more secure emission-reducing activities under the governance provided by the FLEGT. The interaction between the FLEGT and the EU REDD+ fosters forest governance reforms, and it encourages the participation of involved stakeholders and balances possible conflicting interests among them. Additionally, it serves as a distributer of REDD+-relevant information and specialized knowledge to EU decision-making institutions and the partner countries (EU REDD+ Facility, 2014).

\subsubsection{Global Climate Change Alliance}

In 2007, the EU launched the Global Climate Change Alliance initiative to help developing nations cope with climate change. It encourages dialogue and cooperation, particularly with the least developed states that have few resources to deal with climate change impacts. It prioritizes five policy areas: poverty reduction, climate change adaptation, reducing emissions from deforestation and forest degradation, fostering participation in carbon markets, and cutting the risk of climate change-driven disasters. It plays a role as the platform on which the EU offers technical and financial aid to developing states so that the effects of climate change can be incorporated into the countries' national policies, and that their budgets can be allocated for climate change mitigation and adaptation (Global Climate Change Alliance [GCCA], 2012). Agreements from the initiative are supposed to be referred and discussed at the COP to UNFCCC. Through this initiative, the EU is creating incentives and offering them to bolster countries' efforts to reduce greenhouse gas emissions and protect their forests, thereby ensuring the preservation of the livelihoods of local people who depend on forests.

\subsubsection{EU Green Public Procurement (GPP)}

The EU Commission rolled out a plan to encourage the EU's public authorities to purchase products and services that have as little impact as possible on the environment (European Commission, 2015c). It was designed to use 
their massive public purchasing power to provide low-carbon or green markets with needed products and services. Because the GPP releases environmental sustainability criteria for such products and services, EU Member States are attempting to comply with these criteria by amending their national laws to ensure that they are compatible with the GPP. This leaves room for improvement, because the GPP is obligatory. For public institutions, purchasing only environmentally sustainable products and services cannot always be the easiest option in terms of budget planning. However, it is likely that the scheme can contribute to increasing the market shares of such products and services by increasing consumer demand, thereby enticing the private sector to increase its production. Two directives that were adopted by the European Parliament and the European Council are deemed to be sufficiently overarching to represent the EU's current public procurement policy. One of them deals with the supply, service, and work contracts that EU institutions sign with their counterparts (European Commission, 2004a). The other one references the procedures of procurement by public authorities that operate in the sectors of transport, energy, water, and postal services (European Commission, 2004b). The EU and its counterparts are supposed to ensure that the timber products that are traded come from legitimate supply chains. In this context, it should be noted that timber, timber products, and relevant timber-related services constitute an important part of the EU GPP.

\section{The EU's REDD + Policy Implementation in West Papua and Papua, Indonesia}

The EU is presently in the stage of negotiating to implement its REDD+ policy while simultaneously implementing its policy in three continents: Africa, Asia, and Latin America. The Republic of the Congo, the Democratic Republic of the Congo, and Côte d'lvoire in Africa, Indonesia, Laos, and Vietnam in Asia, and Guyana and Honduras in Latin America are the areas that the EU is presently either negotiating with for the VPA or in the stage of REDD+ implementation (EFI, 2014). This chapter deals with the ongoing EU REDD+ project in West Papua and Papua, Indonesia, to see what activities the EU focuses on in terms of its REDD+ policy and what challenges are arising during its implementation. The article has chosen the Indonesian case because the EU's REDD+ policy implementation stage in the area has turned out to be the most developed among the Asian countries that have signed the VPA, and the project is ongoing at the EU level. First, an overview of Indonesia and the regions of West Papua and Papua, in terms of forest and forest loss, will be presented so that the reader will have a better understanding of EU REDD+ policy implementation in these regions.

\subsection{Forest, forest Loss, and Their Drivers in West Papua and Papua, Indonesia}

Indonesia has a forest area of 94.432 .000 hectares (Food and Agriculture Organization of the United Nations [FAO], 2010). It is the third largest emitter of greenhouse gases that result from forest loss. Approximately 24 million hectares of forests were lost from 1990 to 2010 (FAO, 2010). Illegal logging, coal mining, forest fires, and reckless expansion of large-scale tree and oil palm plantations are believed to be the primary drivers of the loss (FAO, 2010; Indrarto et al., 2012). The country, 60\% percent of which is covered by forests, is the largest tropical timber exporter in the world, and it exports a variety of timber products such as plywood, pulp, paper, wooden furniture, and handicrafts (European Forest Institute [EFI], 2014). Additionally, it is the first Asian country to have negotiated and signed the VPA with the EU. It is a beneficiary of funding from the FCPF and the World Bank as well.

West Papua is the second least populous province of Indonesia, and Papua is the province with the most intact forest among the Indonesian islands (Howell \& Bastiansen, 2015). West Papua lost 22.389 hectares of forests from 2011 to 2012, whereas Papua lost 64.230 hectares of its forest during the same period (Mongabay, 2014). Given the fact that Indonesia lost a total of 840.000 hectares of forests in 2012 alone (Mongabay, 2014), the forest loss in both of these provinces is relatively minor. However, it is worrisome that forest loss is increasing steadily in these provinces. The drivers of forest loss in these provinces are similar to those at the national level, and they include large-scale palm oil and jatropha plantations that produce biofuels and other related products, as well as logging and mining (Howell \& Bastiansen, 2015). Although the number of palm oil development businesses is increasing rapidly in the eastern part of Indonesia, West Papua and Papua have a lower rate of forest loss compared with the region as a whole. However, it can be expected that deforestation and forest degradation that is caused by logging in these provinces is going to increase as the production of palm oil increases. In particular, considering the size of the forest area of Papua, one-third of that of Indonesia as a whole, it is important to ensure the effectiveness of any measures that are targeted at preventing forest loss.

\subsection{The EU REDD+ Project in West Papua and Papua}

The EU REDD+ Facility, the backbone of the EU's REDD+ policy, is conducting activities to minimize the negative effects coming from the drivers of deforestation and forest degradation in West Papua and Papua. The EU REDD+ Facility is now currently working in conjunction with Yayasan Penelitian Inovasi Bumi, an 
associated company of the Earth Innovation Institute in these regions. The project is scheduled to run from 2013 to 2016 with funding of 0.2 million Euros from the EU (EFI, 2014). The primary aim is to enhance land use governance by ensuring that land tenure and land use rights in these regions are modified to increase their clarity. The project uses several approaches to attain this objective. First, it believes that the economic, spatial, and social aspects of the timber industry in these regions should be analyzed at the provincial level. Additionally, it searches for opportunities to include local governments and local communities in the decision-making process regarding land use and forest management planning. Finally, the project is developing a system that can monitor the sustainability of a jurisdiction at a level at which significant decisions concerning land use should be taken. Because the project is ongoing, a few of challenges are being identified and they include (EFI, 2014; Earth Innovation Institute, 2014) illegal logging, enforcement of forest and forestry-related laws, and land tenure reform. Identifying these challenges and determining ways to minimize, if not overcome, their impacts are worthy of further discussion. Furthermore, it can be foreseen that the success of the project will result in the implementation of other REDD+ projects somewhere else in the near future. Therefore, the next section of the article will present further discussions and considerations regarding the development of the EU's REDD + policy.

\section{The Challenges and Considerations for Future Policy Development}

This section of the article analyses and discusses the aforementioned challenges to identify more clearly the gravity of each challenge. Subsequently, further considerations regarding each challenge and the potential ways to ease the challenges will be assessed.

\subsection{Illegal Logging}

Logging is destructive, and it plays a critical role in greenhouse gas emissions. It is not just a matter of forest loss; it exposes the area to the risk of flooding that can jeopardize ecosystems and reduce biodiversity in flooded areas. It could eventually lead to infertile soils. It is obvious that illegal logging could trigger more devastating effects. It is safe to say that the degree and extent of the liability for illegal logging varies depending on the logging area and its cause. Additionally, the degree of illegal logging is regarded as an indicator of the level of corruption in some countries (Angelsen et al., 2009). However, illegal logging can be somehow connected to making a living. Thus, it can be difficult to completely eradicate illegal logging unless there are alternative means by which people can make a living. Illegal logging is deeply associated with land tenure, and illegal logging is likely to be found in underdeveloped forested areas where the land tenure is unclear. This is applicable to lands with customary rights as well. Because the ultimate cause of illegal logging is to improve livelihoods, evaluating forest management by local governments and local communities, and rewarding them for their performance could be an effective approach to limit illegal logging (EU REDD+ Facility, 2014; UNFCCC 2012). It is understood that sustainable forest management is vulnerable to livelihood conditions in communities (Duguma et al., 2014), and that purchasing illegal timber can exacerbate this problem. In this context, it is necessary to establish a legal verification system (Pohnan \& Stone 2013). Even after timber products enter local areas illegally, a firmly established legal set-up that provides a strict verification method would block the circulation of illegal timber, thereby stemming its widespread use. Reporting illegal logging to competent authorities would curb its spread; however, it is not likely that the reporting system, if conducted at the level of individuals, would solve the problem, as there is a possibility that the identity of the reporter could be exposed, which could cause frictions within small communities. Furthermore, it could lead local people to create an organized group that increases illegal logging. In cases in which businesses are provided with concessions or quotas for logging to produce secondary timber products, such as biofuels and medical products, the situation can be more complicated, as it is, to some extent, linked to forest administration. However, when legal arrangements encourage the enforcement of monitoring systems and provide incentives to locals to improve their forest management practices, illegal logging could be curtailed effectively. Furthermore, deforestation triggered by over-exploitation of forests, as occurs during illegal logging, should be able to be tackled more easily than expected (Skutsch et al., 2011). Other than the livelihood-centered approach, setting low initial CER values from the REDD+ projects in illegal logging areas can be instrumental in encouraging REDD+ businesses to be more actively involved in forest management, without decreasing their profitability.

\subsection{Land Tenure}

The issue of land tenure plays a significant role in REDD+ policy in that the land owner is in the legal position to decide how the land is to be used, and their decision has either positive or negative impacts on the land. The right to land becomes problematic when land ownership is not defined clearly, which can be viewed as a governance issue. In most cases, customary rights to land in local communities are not recognized at the state level (Carbon Trade Watch, 2013), which causes more serious problems. Customary law assures one's legitimacy to own the 
land (Galudra et al., 2014), and it is important to clarify land tenure when making decisions that involve the interests of the multiple parties that are involved in the REDD+ policy process. Indigenous people in the project area can be faced with overlapping ownership of the area, and land grabbing can occur when new, external participants engage in the project (Larson et al., 2013). Additionally, in the worst cases, indigenous people can be exploited because they are not aware of their land ownership rights (Angelsen et al., 2012). When it is difficult to secure land tenure, it is critical for indigenous people to secure their right to engage in forest management and verify the forest boundary. These procedures may be complex, and they require consent from the local and national governments (van Noordwijk et al., 2013). However, if this occurs, implementing these measures could be a way in which to overcome difficulties in defining land ownership rights. Another possible measure is to shorten the compulsory holding period for the legitimate registration of lands with customary rights to simplify and clarify the legal set-up concerning land ownership. It is typical that governmental institutions and private businesses take part in REDD+ projects. A large volume of technical and financial assistance from these actors could make indigenous people feel insignificant and put them at a disadvantage during the decision-making process. Thus, securing legitimate land tenure can be instrumental in raising their voice in the process by acting as a basic, but fundamental, institutional measure. REDD+ is a policy area where land-related institutions are somehow connected to each other because REDD+ implementation deals with land use and land use change. Because it takes a long time for a policy to produce a policy outcome, the REDD+ policy area can be sidelined by other relevant, faster-progressing policy areas. Paradoxically, if the project fails, every administrative unit involved in the project, not just the competent authority in charge of the REDD+ project, would share the responsibility (Larson et al., 2013). This indicates that the security of land tenure in REDD+ is not just a testament to whether an entity owns land, but also suggests that this issue can expand beyond the competent authority and involve more complex issues among other relevant authorities. Hence, a country that is involved in REDD+ should formulate a measure that encompasses policies at the local and project levels. As a bottom-up approach to complement this measure, civil organizations consisting of local experts can contribute to REDD+ to a considerable extent, as they know how to enforce the customary land tenure rights of indigenous people, as well as how to set up a more inclusive decision-making process that represents their communities.

\subsection{Law Enforcement}

Most countries with the potential to take part in REDD+ have shown poor performance in forest governance (Skutsch \& McCall, 2010). REDD+ project areas are vulnerable to illegal acts, such as timber- and financial-related crimes because of weak governance, poor regulatory systems, and the nature of investment (Anti-Corruption Resource Center, 2013). Hence, it is important to have effective law enforcement in the REDD+ project area to achieve a successful outcome, especially because law enforcement can deal with trade-relevant measures that the VPA is not capable of addressing (Luttrell et al., 2011). As the REDD+ policy area overlaps with other policy areas, it is essential to clarify the nature of conflicted regulations. Notably, uncertainty surrounding regulations regarding penalties for violating the law in policy areas with weak governance allows criminals to defend their violations to some extent. Additionally, the balance between the rigorousness and the acceptability of laws to the local people should be taken into consideration. Although regulatory instruments are deeply relevant to enhancing law enforcement (Matthews et al., 2014), if the nature of the concerned regulation is too severe, it can generate backlash among the local people and create loopholes in law enforcement. Local people in rural areas have strong ties with one another, as it is most likely that their families have been neighbors for many generations. This makes it possible to establish ties between the local people and the law enforcement personnel in the area. Because of such close civic ties, law enforcement can be problematic, as these ties can induce law enforcement personnel to engage in a range of misconducts, which weakens the legal compliance of the entire community and jeopardizes the integrity of the REDD+ project in the long run. To prevent this from happening, it is recommended that law enforcement personnel be recruited from outside the community. In terms of forest management, illegal acts that are performed unwittingly by the local people for a long period of time may require educational efforts to ensure that the local community is fully aware of the impact of their actions on the effective implementation of REDD+ projects in their communities. This is why regular meetings, such as town hall meetings, should be held to educate the local people about the progress of the project. This would create opportunities for all of the parties to better understand each other with respect to the ongoing REDD+ project. It is expected that such secondhand education enables more active participation by the local people in the project, as well as greater cooperation with law enforcement officers. In particular, if these educational activities were centered upon the profits that can be shared from the project, they would generate greater cooperation in enforcing the law while the project is underway. A different approach would be to impose the importance of collective responsibility upon the local people by paying them less if criminal activities occur in their assigned area. This approach may remind the local people of the importance of their 
collective responsibility for forest management as well. EU REDD+ project implementation areas, although few in number, are thought to have different types and rates of crime because they experience different drivers of deforestation and forest degradation. Because the REDD+ policy area overlaps, and even conflicts, with other policy areas, and is not prone to display its effectiveness in the short term, the policy may not be prioritized. The clarity, transparency, and, above all, fairness of enforcing the law should be required elements of REDD+.

\section{Conclusion}

As discussed earlier, the EU's REDD+ policy is being implemented under the VPA in several countries besides Indonesia. The challenges from the ongoing project in West Papua and Papua, namely, enforcing land tenure, strengthening law enforcement, and eradicating illegal logging, are also factors that should be considered by the EU when implementing REDD+ in other areas. The primary challenges facing REDD+ vary depending on the country, region, and local area. However, because the majority of the countries that are in the negotiating stage of the VPA, or the preparation stage for signing the VPA with the EU, are developing countries, they may face common challenges. It is highly anticipated that the EU's REDD+ policy area will develop further with time as the EU's capability of establishing the greenhouse gas emissions resulting from land use and land use change is expected to improve, as is the MRV system. Furthermore, EU Member States will intensify their efforts to acquire offsets from REDD+ under the EU ETS to offset their EUAs. However, it is unquestionably urgent to first come up with better remedies for the challenges that the EU faces during the REDD+ implementation stage, rather than expending effort to improve well-established systems, including accounting under the EU ETS. The desire to overcome these challenges during the implementation stage will be the primary driving force behind the development of the EU's REDD+ policy, regardless of the countries in which the EU implements REDD+ in the future. It can be said that the article provides significance and originality to some degree in that it discusses the EU's REDD+ policy direction and the lessons from the empirical side by dealing with the EU's REDD+ policy developments, the implementation project, and the lessons from it for further related research.

\section{Limitations}

Detailed analyses and subsequent discussions concerning the reasons for deforestation and forest degradation in $t$ he West Papua and Papua regions could have increased the value of this article. However, it is believed that they might not be relevant to the intended purpose of the article, as the article intended to provide a primary overview of the EU's REDD+ policy developments and to identify key challenges facing the EU's REDD+ projects that ar e currently underway, as well as to generate discussion for more effective implementation of the EU REDD+ pol icy in the future. Additionally, the process used to identify the challenges facing the ongoing REDD+ projects in Indonesia has been omitted for the same reason.

\section{References}

Angelsen, A., Brockhaus, M., Kanninen, M., Sills, E., Sunderlin, W. D., \& Wertz-Kanounnikoff, S. (2009). Realizing REDD+: National strategy and policy options. Bogor: Center for International Forestry Research.

Angelsen, A., Brockhaus, M., Sunderlin, W. D., \& Verchot, L. V. (2012). Analyzing REDD+ challenges and choices. Bogor: Center for International Forestry Research.

Anti-Corruption Resource Center. (2013). Project Leaf and addressing corruption. REDD+, U4 Brief No.3. Bergen. $\quad$ Retrieved

from https://www.cmi.no/publications/4894-project-leaf-and-addressing-corruption-in-redd

Carbon Trade Watch. (2013, April). Protecting carbon to destroy forests: Land Enclosures and REDD+. Project paper presented from a Joint Project of TNI, FIAN International, FIAN Netherlands, FIAN Germany, FIAN Austria, IGO in Poland and FDCL in Germany. Retrieved from http://www.carbontradewatch.org/downloads/publications/REDD_and_land-web.pdf

Duguma, L. A., Minang, P. A., \& Van Noordwijk, M. (2014). Climate change mitigation and adaptation in the land use sector: From complementarity to synergy. Environmental Management, 54, 420-32. https://doi.org/10.1007/s00267-014-0331-x

$\begin{array}{llll}\text { Earth Innovation } & \text { Institute. } & \text { (2014). } & \text { Retrieved }\end{array}$ http://earthinnovation.org/our-work/regional-initiatives/indonesia/west-papua/

EU REDD+ Facility. (2014). Linking FLEGT and REDD+. Briefing. European Forest Institute. Retrieved from http://www.euredd.efi.int/documents/15552/154912/Linking+FLEGT+and+REDD\%2B/7152b991-8ae6-4c 8a-8679-02c1fbb1765e

European Commission. (2003). Communication from the Commission to the Council and the European 
Parliament, Forest Law Enforcement. Governance and Trade Proposal for an EU Action Plan', COM 251 Final. Brussels.

European Commission. (2004a, March 31). Directive 2004/17/EC of the European Parliament and of the Council of 31 March 2004 coordinating the procurement procedures of entities operating in the water, energy, transport and postal service sectors. Brussels. Retrieved from http://eur-lex.europa.eu/legal-content/EN/TXT/?uri=celex:32004L0018

European Commission. (2004b, March 31). Directive 2004/18/EC of the European Parliament and of the Council of 31 March 2004 on the coordination of procedures for the award of public works contracts, public supply contracts and public service contract. Brussels. Retrieved from http://eur-lex.europa.eu/legal-content/EN/TXT/?uri=celex:32004L0018

European Commission. (2008, October 17). Communication from the Commission to the European Parliament, the Council, the European Economic and Social Committee and the Committee of the Regions: Addressing the challenges of deforestation and reforest degradation to tackle climate change and biodiversity loss. Brussels. Retrieved from http://eur-lex.europa.eu/legal-content/EN/TXT/PDF/?uri=CELEX:52008DC0645\&from=EN

European Commission. (2009, April 23). Directive 2009/29/EC of the European Parliament and of the Council 23 April 2009 amending Directive 2003/87/EC so as to improve and extend the greenhouse gas emission allowance trading scheme of the Community. Brussels. Retrieved from http://eur-lex.europa.eu/legal-content/EN/TXT/PDF/?uri=CELEX:32009L0029\&from=EN

European Commission. (2015a). 2020 Climate and Energy Package. European Union. Retrieved from https://ec.europa.eu/clima/policies/strategies/2020_en

European Commission. (2015b). Combating tropical deforestation: the REDD+ initiative. Retrieved fromhttps://ec.europa.eu/clima/policies/forests/deforestation_en

European Commission. (2015c). Green Public Procurement. Retrieved from http://ec.europa.eu/environment/gpp/index_en.htm

European Council. (2008). Council conclusions on addressing the challenges of deforestation and forest degradation to tackle climate change and biodiversity loss. Brussels. Retrieved from http://eur-lex.europa.eu/legal-content/EN/TXT/PDF/?uri=CELEX:52008DC0645\&from=EN

European Council. (2012, May 15). Council Conclusions on climate finance - fast start finance'. The 3167th Economic and Financial Affairs Council meeting. Brussels. Retrieved from file:///C:/Users/504-08/Desktop/130262.pdf

European Council. (2014, October 23). Conclusions on 2030 Climate and Energy Policy Framework. SN 79/14. Brussels.

from https://www.consilium.europa.eu/uedocs/cms_data/docs/pressdata/en/ec/145356.pdf

European Forest Institute (2014). Retrieved from http://www.efi.int/portal/

Food and Agriculture Organization of the United Nations. (2009, June 4). Foreign direct investment: Win-win or land grab. Policy Brief. Rome. Retrieved from https://usaidlandtenure.net/wp-content/uploads/2016/09/USAID_Land_Tenure_2012_Liberia_Course_Mod ule_2_From_Land_Grab_to_Win_Win_FAO.pdf

Galudra, G., van Noordwijk, M., Agung, P., Suyanto, S., \& Pradhan, U. (2014). Migrants, land markets and carbon emissions in Jambi, Indonesia: Land tenure change and the prospect of emission reduction. Mitigation and Adaptation Strategies for Global Change, 19(6), 715-731.

Global Climate Change Alliance. (2012, November). Using innovative and effective approaches to deliver climate change support to developing countries. UK. Retrieved from https://ec.europa.eu/clima/sites/clima/files/docs/gcca_brochure_en.pdf

Howell, S., \& Bastiansen, E. (2015). REDD+ in Indonesia 2010-2015. Paper from the Department of Social Anthropology, University of Oslo, Norway and Universitas Gadjah Mada, Yogyakarta, Indonesia. Retrieved from https://www.sv.uio.no/sai/bilder/publikasjoner/redd\%2B-in-indonesia-2010-2015.pdf

Indrarto, G., B., Murharjanti, P., Khatartina, J., Pulungan, I., Ivalerina, F., Rahman, J., .. Muharrom, E. (2012). The context of REDD+ in Indonesia: Drivers, agents, and institutions. Working paper No. 92, Center for International Forestry Research, Bogor, Indonesia. Retrieved from 
https://www.cifor.org/publications/pdf_files/WPapers/WP92Resosudarmo.pdf

Larson, A., M., Brockhaus, M., Sunderlin., W., D., Duchelle, A., Babon, A., Dokken, T., ... Huynh, T-B. (2013). Land tenure and REDD+: The good, the bad, and the ugly. Global Environmental Change, 23(3), 678-689. https://doi.org/10.1016/j.gloenvcha.2013.02.014

Luttrell, C., Obidzinski, K., Brockhaus, M., Muharrom, E., Petkova, E., Wardell, D., A., \& Halperin, J. (2011). Lessons for REDD from measures to control illegal logging in Indonesia. Working Paper No. 74, CIFOR, United Nations Office on Drugs and Crime, Vienna. Retrieved from https://www.cifor.org/publications/pdf_files/WPapers/WP74Obidzinski.pdf

Matthews, R., B., van Noordwijk, M., Lambin, E., Meyfroidt, P., Gupta, J., Verchot, L., ...Veldkamp, E. (2014). Implementing REDD+ (Reducing Emissions from Deforestation and Degradation): Evidence on governance, evaluation and impacts from the REDD-Alert project. Mitigation and Adaptation Strategies for Global Change, 19(6), 907-925. https://doi.org/10.1007/s11027-014-9578-z

Mongabay. (2014). Despite moratorium, Indonesia now has world's highest deforestation rate. Retrieved from https://news.mongabay.com/2014/06/despite-moratorium-indonesia-now-has-worlds-highest-deforestation-r ate/

Pohnan, E., \& Stone, M. (2013). Can legality verification combat illegal logging in Indonesia? Strategic insights for policy makers and advocates. IUFRO Occasional paper No.6, International Union of Forest Research Organizations, Vienna. Retrieved from https://pdfs.semanticscholar.org/b8c0/fa2e3b6d537308db922f3e5c480decec8fd7.pdf

Skutsch, M., M., \& McCall, M., K. (2010). Reassessing REDD: Governance, markets and the hype cycle. Climatic Change, 100(3), 395-402. https://doi.org/10.1007/s10584-009-9768-y

Skutsch, M., M., Torres, A., B., Mwampamba, T., H, Ghilardi, A., \& Herold, M. (2011). Dealing with locally-driven degradation: A quick start option under REDD+. Carbon Balance and Management, 6, 16. https://doi.org/10.1186/1750-0680-6-16

$\begin{array}{lllll}\text { UNFCCC. } & \text { (2007). } & \text { Bali } & \text { roadmap. } & \text { Retrieved }\end{array}$ http://unfccc.int/key_documents/bali_road_map/items/6447.php

UNFCCC. (2011). Durban Climate Change Conference. Retrieved from http://unfccc.int/meetings/durban_nov_2011/meeting/6245.php

UNFCCC. (2012, September). REDD+: An incentive structure for long-term performance. A discussion paper, $\begin{array}{lllll}\text { presented at } & \text { UNFCCC }\end{array}$ http://www.fern.org/sites/fern.org/files/broad_performance_paper_V1_web.pdf

UNFCCC. (2014). Lima Agreements. Retrieved http://newsroom.unfccc.int/lima/lima-call-for-climate-action-puts-world-on-track-to-paris-2015/

Van Noordwijk, M., Agus, F., Dewi, S., \& Purnomo, H. (2013). Reducing emissions from land use in Indonesia: Motivation, policy instruments, and expected funding streams. Mitigation Adaptation Strategies for Global Change, 19(6), 677-692.

\section{Copyrights}

Copyright for this article is retained by the author(s), with first publication rights granted to the journal.

This is an open-access article distributed under the terms and conditions of the Creative Commons Attribution license (http://creativecommons.org/licenses/by/4.0/). 